\title{
Ecological Survey on a Recently Disturbed Plant Community in Nnamdi Azikiwe University Awka, Anambra State
}

\author{
K.U. Ekwealor ${ }^{1}$, C.F. Iroka ${ }^{1, *}$, G.C. Ukpaka ${ }^{2}$, P.N. Okeke ${ }^{1}$, K.E. Okereke ${ }^{1}$, P.N. Okafor ${ }^{3}$ \\ ${ }^{1}$ Department of Botany, NnamdiAzikiwe University Awka, Nigeria. \\ ${ }^{2}$ Department of Biological Sciences, Chukwuemeka Odumegwu Ojukwu University, Uli, Nigeria. \\ ${ }^{3}$ Department of Biology Education, Federal College of Education Technical Umunze, Nigeria.
}

Received November 27, 2019; Revised January 9, 2020; Accepted January 13, 2020

Copyright $\bigcirc 2020$ by authors, all rights reserved. Authors agree that this article remains permanently open access under the terms of the Creative Commons Attribution License 4.0 International License

\begin{abstract}
Ecological survey on a recently disturbed plant community in NnamdiAzikiwe University Awka premises was carried out using random sampling method. The species present within the quadrat were identified, counted and recorded. Only plants that were rooted within the quadrat were included. Abundance values obtained from quadrat samples for plot 1 showed that Pennisetumpurpureumhad the highest density followed by Bidenspilosa and Calapagoniummucunoides, whileChlorispilosa,Gomphrenac elosoides, Paspalumscrobiculatum and Sidalinifolia were of the lowest density, followed by Combretumhispidum. Abundance values obtained from quadrat samples for plot 2 showed thatAspiliabussei had the highest density followed by Sidaacuta, then Ageratum conizoides while Sidalinifolia, Combretumhispidium, Hiptislanceolata and Celosia leptoscachya had the lowest density. Abundance values obtained from quadrat samples for plot 3 showed thatAspiliabussei had the highest density followed by Calapagoniummucunoides, then Paspalumscrubiculatum, while Sidalinifolia, Hiptislanceolata, Panicum maximum and Chlorispilosa had the lowest density. From the study, it was observed that plot 1 had the highest species diversity followed by plot 2 and plot 3 . In general the mean value of this species diversity is 0.77 which confirms that the area is highly diverse and the species diversity are highly related.The species diversities are not significantly different from one another, showing how homogenous the three plots were.
\end{abstract}

Keywords Ecological, Species, Diversity, Density, Plants, Population, Community

\section{Introduction}

Species distribution and abundance are fundamental to understanding patterns of communities and their relations to environmental conditions [1] [2]. One of the most basic steps in vegetation analysis is classification of community types. Classification is the process of grouping similar entities together into classes based on selected shared characteristics [3]. In the case of plant communities, vegetation and environmental features are used to describe units that are useful for management applications [4] [5].

In any ecological study, the vegetation is considered. [6]described vegetation as an assemblage with plants growing together in a particular location and may be characterized either by its component species or by the combination of functional and structural character that characterizes the appearance of the vegetation. This is an important distinction which is reflected by the range of methods available for describing the vegetation. Structural methods do not demand species identification and are often considered more meaningful for small-scale (large area) studies and for habitat description for scientists of other disciplines. Methods based on species composition or floristic are more useful for large-scale (small area) studies of a more detailed botanical nature.

Different vegetation types require different quadrat sizes. [7]noted that vegetation with smaller plants, greater plant density or greater species diversity needs smaller quadrat. He also stated that a better approach is to determine the particular quadrat type and size for a particular study. One common scenario faced in abundant species studies is that the species habitat lies along a boundary with complex geometry. Some examples include surveys conducted along coastlines, Rivers, Lake Shores and elevation contours. Many transect-quadrats designed in this setting gives size to uneven selection probabilities over the survey region. The 
non uniformity in sampling coverage must be properly accounted for in the estimation procedure to avoid introducing bias into the abundance estimate. [8]provided a simple solution to this, namely: by weighing each data point (quadrat in the correct context) using the inverse of the corresponding selection probability.

[9]noted that one qualitative method of analysis of a community is to list all the species present. He subsequently argued that such a check list is useful but it is rarely used alone because of its limited value, and that quantitative data are also required. In actual situation, it is not often possible to carry out a complete quantitative analysis because of its large size. It is better to choose a small area when detailed analysis is required. The method in which the samples are distributed is important. For instance, if the samples were systematically and evenly spaced out over the community, each sample should be placed at random. This is important because it is necessary to be able to estimate the mean or average values of various characters of the vegetation.

This study seeks to carry out quantitative analysis on a recently disturbed plant community, by; determining the species type and diversity in the community. Each community is composed of taxonomically different species and in determining species diversity, species richness and evenness will also be considered.Also the study will determine the stability of the community. For a community to be stable, it requires two components: Resilienceand Resistance. Resilience is the ability of a community to recover after facing a disturbance or displacement. Resistance, on the other hand, is the ability of a community to avoid disturbance. The structure and composition of the community will also be determined. Each community has its own structure and composition. Community structure is often expressed in terms of its major growth form such as trees in forests or grasses in grasslands. The arrangement of different growth forms determines the structural pattern of the community.

\section{Materials and Methods}

\subsection{Site Description}

Awka is located between the coordinates $6^{\mathrm{O}} 12^{\prime} 25 \mathrm{~N}$ and $7^{\circ} 04^{\prime} 04 \mathrm{E}$. Awka is in the tropical rainforest zone of Nigeria and experiences two distinct seasons brought about by the predominant winds that rule the area. The Southwestern monsoon winds from the Atlantic Ocean and the Northeastern dry wind across the Sahara desert. The monsoon winds from the Atlantic creates seven months of heavy tropical rains which occurs between April and October and followed by five months of dryness November to March. The harmattan is particularly dry and dusty wind which enters Nigeria in late December or in early part of January and is characterized by gray haze limiting visibility and blocking the sun's rays. The temperature in Awka is generally $27^{\circ} \mathrm{C}$ to $30^{\circ} \mathrm{C}$ between June and December $32^{\circ} \mathrm{C}$ to $34^{\circ} \mathrm{C}$ between January and April with the last few month of dry season marked with intense heat.The quantitative analysis study was carried out in a large area of plant community opposite the digital library complex of NnamdiAzikiwe University Awka. The study area was of uniform elevation and homogeneous. This means that it has similar environmental parameters, vegetation and management history.

Three different study areas, measuring $8 \mathrm{~m}$ by $8 \mathrm{~m}$ were mapped out using pegs to map out the four corners of the plot and two $30 \mathrm{~m}$ tape to measure $8 \mathrm{~m}$ for each side of the plot, a cutlass for making small holes. The holes were for inserting the pegs. And a $1 \mathrm{~m}$ by $1 \mathrm{~m}$ quadrat was used. Before sampling, the sampling intensity was calculated which gave approximately $16 \%$.

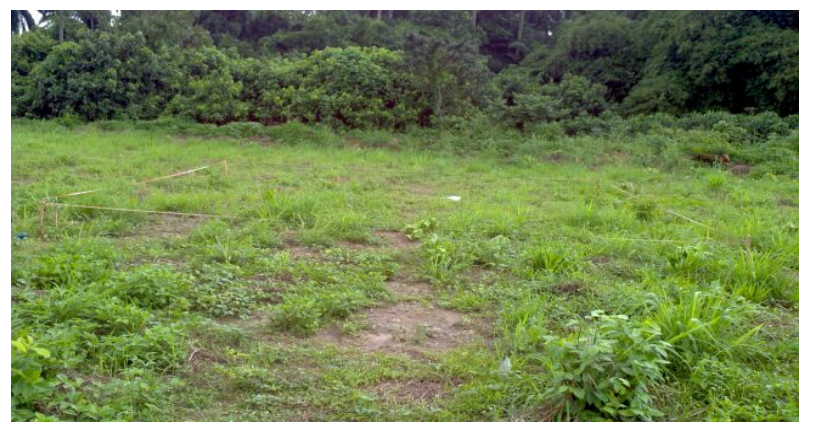

Figure 1. Photograph of plot 1

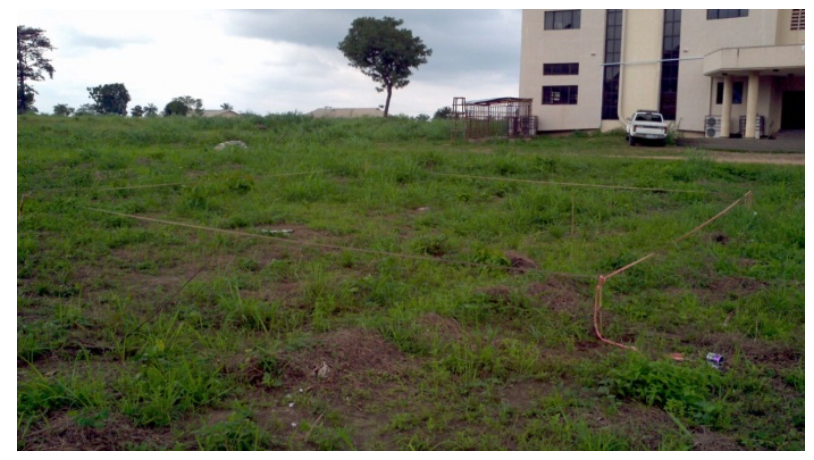

Figure 2. Photograph of plot 2 and 3

\subsection{Sampling Technique}

The random sampling method was used for sampling. Two coordinates $\mathrm{AB}$ (8m to represent 8 units) and BC (8 m to represent 8 units) were measured out in each plot (Refer Figs 1 and 2). Pieces of papers were used to write numbers 1 to 7 separately for each value of $\mathrm{AB}$ and $\mathrm{BC}$. These numbers were folded and picked at random 10 times in order to get the random points where the quadrats will be placed. Number 8 was avoided in the written numbers to avoid edge effect i.e. getting the random points at the edge of the mapped out plots, or even outside it.At each random point, the quadrat was placed in such a way that the point of intersection is in the center of the quadrat. The species present within the quadrat 
were identified, counted and recorded. Only plants that were rooted within the quadrat were included (refer to Figs 3, 4 and 5). This procedure continued till the ten random points (intersects) were sampled for each of plots 1, 2 and 3 .

Coded alphabets were given to all plants that could not be identified in the field. The unidentified plants were collected, properly labelled and taken to Department of Botany Herbarium NnamdiAzikiwe University for identificationDr. E.I. Mbaekwe and Mr C.F. Iroka. Floras, monographs and hand book of West African weeds by[10] [11] was used.

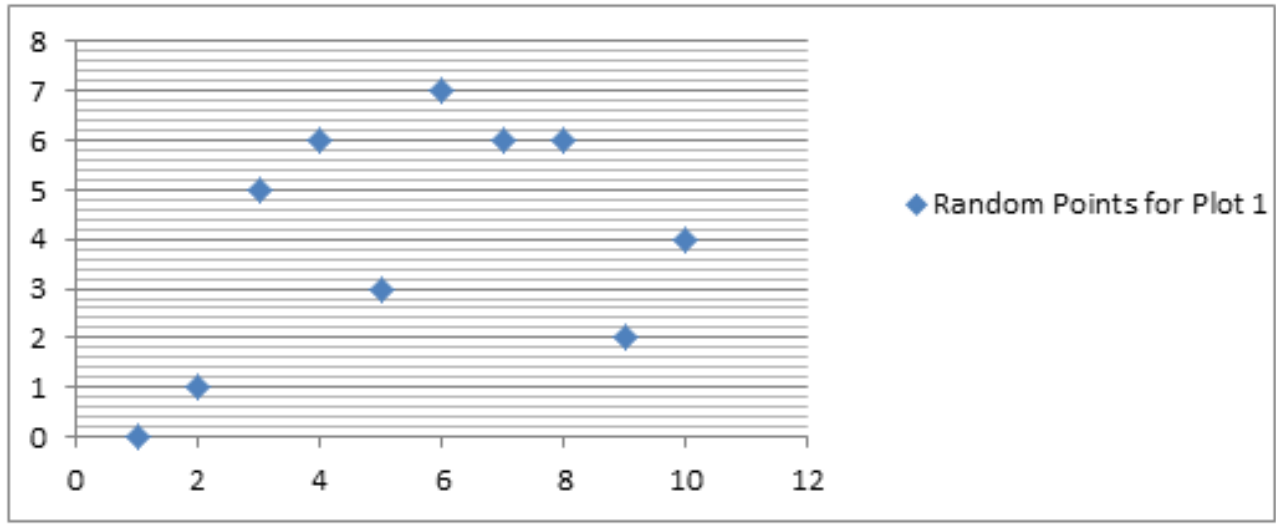

Figure3. Random Points Used for Sampling Plot 1

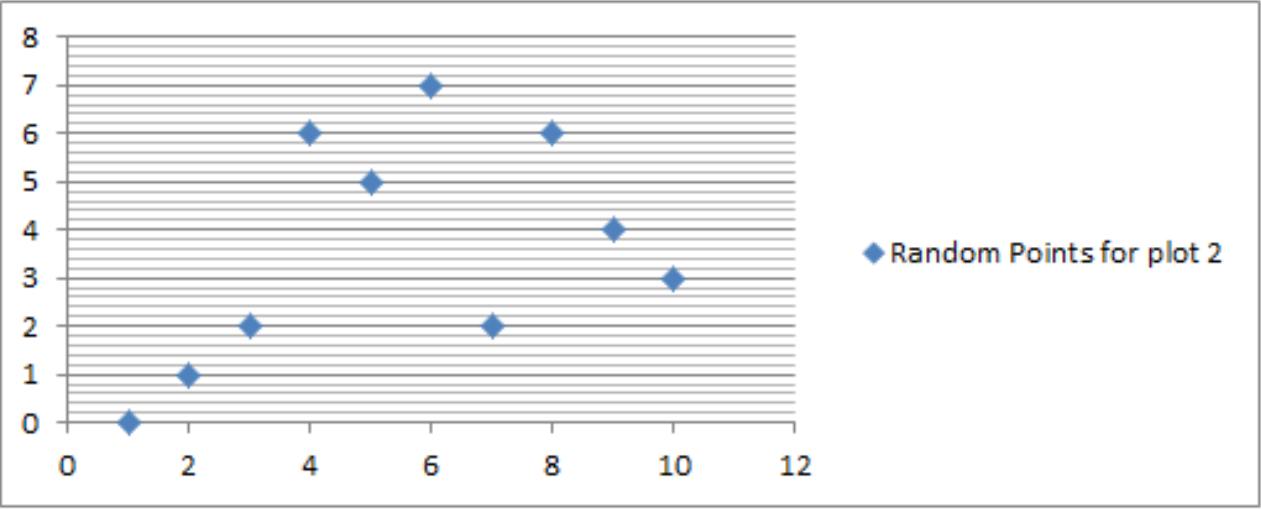

Figure4. Random Points Used for Sampling Plot 2

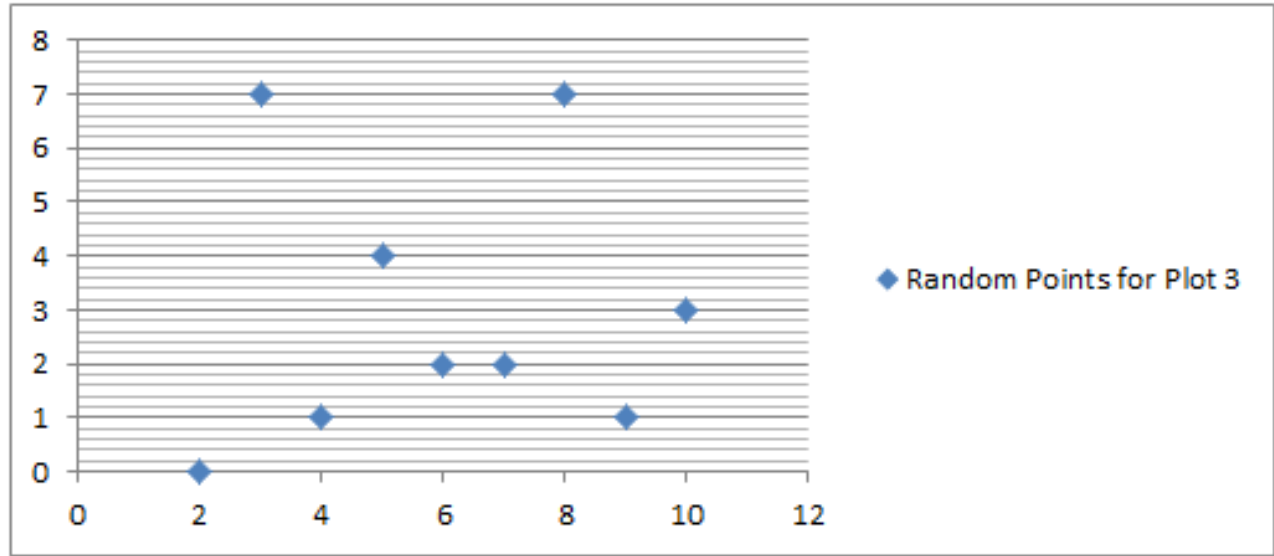

Figure5. Random Points Used for Sampling Plot 3 


\subsection{Data Analysis}

From the records obtained from plots 1, 2, 3, the following calculations were done.

1. Density $=\frac{\text { totalnumberofindividualspecies }}{\text { totalareaoftheplotsampled }}$

2. Relative density $=\frac{\text { densityofonespecies }}{\text { totaldensityofallspecies }} \times \frac{100}{1}$

3. Frequency $=\frac{\text { numberofoccurenceofonespecies }}{\text { numberoftimessampled }} \times \frac{100}{1}$

4. Relative frequency $=\frac{\text { frequencyofonespecies }}{\text { totalfrequencyofallspecies }} \times \frac{100}{1}$

5. Importance value $=$ relative density of one species + relative frequency of the same species

Species diversity was calculated using the Shannon Wienner index and the steps are listed below.

STEP 1:

$$
\mathrm{H}^{\mathrm{I}}=-\sum(p i) \mathrm{x}(\ln p i)
$$

STEP 2:

$$
\mathrm{H}_{\text {max }}=(\ln S)
$$

STEP 3:

$$
\mathrm{E}=\frac{H^{I}}{H_{\max }}
$$

Where:

$\mathrm{Pi}=$ proportion of total sample belonging to the species $\mathrm{S}=$ number of species diversity
$\mathrm{H}^{\mathrm{I}}=$ index of species diversity

$\mathrm{E}=$ equitability / evenness

NOTE: That the values for species diversity range from 0.1 to 0.99

\section{Results and Discussion}

Quadrat Size: $1 \mathrm{~m}$ by $1 \mathrm{~m}$

From the table 1, results showed that Pennisetum purpureum had the highest density followed by Bidenspilosa and Calapagonium mucunoides, while Chloris pilosa, Gomphrena celosoides, Paspalum scrobiculatum and Sida linifolia were of the lowest and of the same density, followed by Combretum hispidum. The table also shows that Calapagonium mucunoides and Pennisetum purpureum had the highest and the same frequency followed by Bidens pilosa while Paspalum scrobiculatum, Sida linifolia, Gomphrena celosoides, Chromolaena odorata, Ipomoea eriocarpa, Aspilia africana, Eleusine indica, Senna obstusifolia, Chloris pilosa had the lowest and the same frequency.The table also showed that Pennisetum purpureum had the highest importance value, followed by Calapagonium mucunoides while Sida linifolia, Paspalum scrobiculatum, Gompherana celosoides had the lowest and

\begin{tabular}{|c|c|c|c|c|c|}
\hline Species & Density $\left(\mathbf{M}^{-2}\right)$ & $\begin{array}{l}\text { RelativeDensity } \\
\text { (\%) }\end{array}$ & Frequency(\%) & RelativeFrequency(\%) & Importance Value \\
\hline Ageratum conyzoides & 2.1 & 6.29 & 30 & 5.26 & 11.55 \\
\hline Aspiliabussei & 3.2 & 9.58 & 40 & 7.02 & 16.6 \\
\hline Aspillia Africana & 0.4 & 1.2 & 10 & 1.75 & 2.95 \\
\hline Axonopuscompressus & 0.7 & 2.1 & 20 & 3.51 & 5.61 \\
\hline Bidenspilosa & 4.5 & 13.47 & 50 & 8.77 & 22.24 \\
\hline Calapagoniummucunoides & 4.3 & 12.87 & 80 & 14.04 & 26.91 \\
\hline Celosia leptoscachya & 0.9 & 2.69 & 30 & 5.26 & 7.95 \\
\hline Chlorispilosa & 0.1 & 0.3 & 10 & 1.75 & 2.05 \\
\hline Chromolaenaodorata & 0.9 & 2.69 & 10 & 1.75 & 4.44 \\
\hline Combretumhispidum & 0.2 & 0.6 & 20 & 3.51 & 4.11 \\
\hline Crotalaria retusa & 3.2 & 9.58 & 20 & 3.51 & 13.09 \\
\hline Cyperusesculentus & 0.5 & 1.5 & 20 & 3.51 & 5.01 \\
\hline Eleusineindica & 0.4 & 1.2 & 10 & 1.75 & 2.95 \\
\hline Gomphrenacelosoides & 0.1 & 0.3 & 10 & 1.75 & 2.05 \\
\hline Ipomoea eriocarpa & 0.3 & 0.9 & 10 & 1.75 & 2.65 \\
\hline Ipomoea involucrata & 1.2 & 3.59 & 30 & 5.26 & 8.85 \\
\hline Lonchocarpuscyanescens & 0.4 & 1.2 & 20 & 3.51 & 4.71 \\
\hline Paspalumscrobiculatum & 0.1 & 0.3 & 10 & 1.75 & 2.05 \\
\hline Pennisetumpurpureum & 7.9 & 23.65 & 80 & 14.04 & 37.69 \\
\hline Sennaobstusifolia & 0.4 & 1.2 & 10 & 1.75 & 2.95 \\
\hline Sidaacuta & 1.5 & 4.49 & 40 & 7.02 & 11.51 \\
\hline Sidalinifolia & 0.1 & 0.3 & 10 & 1.75 & 2.05 \\
\hline TOTAL & 33.4 & & 570 & & \\
\hline
\end{tabular}
the same importance value followed by Ipomoea eriocarpa.

Table 1. Abundance Values Obtained from Quadrat samples for plot 1 
Quadrat Size: $1 \mathrm{~m}$ by $1 \mathrm{~m}$

Table 2. Abundance values obtained from quadrat samples for plot 2

\begin{tabular}{|l|l|l|l|l|c|}
\hline Species & $\begin{array}{l}\text { Density } \\
\mathbf{M}^{-2} \mathbf{)}\end{array}$ & $\begin{array}{l}\text { RelativeDensity } \\
\mathbf{( \% )}\end{array}$ & Frequency(\%) & $\begin{array}{l}\text { RelativeFrequency } \\
(\mathbf{\%})\end{array}$ & $\begin{array}{c}\text { Importance } \\
\text { Value }\end{array}$ \\
\hline Ageratum conyzoides & 6.2 & 24.92 & 80 & 11.76 & 36.68 \\
\hline Calapagoniummucunoides & 3.6 & 8.96 & 90 & 13.24 & 22.2 \\
\hline Celosia leptoscachya & 0.1 & 0.25 & 10 & 1.47 & 1.72 \\
\hline Chlorispilosa & 5.7 & 14.18 & 70 & 10.29 & 24.47 \\
\hline Combretumhispidum & 0.1 & 0.25 & 10 & 1.47 & 1.72 \\
\hline Cyperusesculentus & 0.4 & 1 & 10 & 1.47 & 2.47 \\
\hline Eleusineindica & 2.8 & 6.97 & 50 & 7.35 & 14.32 \\
\hline Euphorbia hirta & 0.3 & 0.75 & 10 & 1.47 & 2.22 \\
\hline Gomphrenacelosoides & 1.1 & 2.74 & 20 & 2.94 & 5.68 \\
\hline Hiptislanceolata & 0.1 & 0.25 & 10 & 1.47 & 1.72 \\
\hline Mimosa invisa & 0.3 & 0.75 & 30 & 4.41 & 5.16 \\
\hline Paspalumscrobiculatum & 1.4 & 3.48 & 50 & 7.35 & 10.83 \\
\hline Pennisetumpurpureum & 4 & 9.95 & 90 & 13.24 & 23.19 \\
\hline Sidaacuta & 6.7 & 16.68 & 60 & 8.82 & 25.5 \\
\hline Sidalinifolia & 0.1 & 0.25 & 10 & 1.47 & 1.72 \\
\hline Sub Ageratum species & 7.3 & 18.16 & 80 & 11.76 & 29.92 \\
\hline TOTAL & $\mathbf{4 0 . 2}$ & & $\mathbf{6 8 0}$ & & \\
\hline
\end{tabular}

From table 2, the results shows that Aspiliabussei has the highest density followed by Sidaacuta, then Ageratum conizoides while Sidalinifolia, Combretumhispidium, Hiptislanceolata and Celosia leptoscachya had the lowest and same density, followed by Euphorbia hirta and Mimosa invisa with the same density. The table also shows that Calapogiummucunoides and Pennisetumpurpureum has the highest and the same frequency followed by Aspiliabussei and Ageratum conyzoideswith the same density while Sidalinifolia, Cypruesculentus, Comberatumhispidium, Euphorbia hirta, Hiptislanceolata and Celosia leptoscachya has the lowest with the same frequency followed by Gomphrenacelosoides. The table also showed that Ageratum conyzoides have the highest importance value followed by Aspiliabussei, then Sidaacuta while Sidalinifolia, Comberatumhispidium, Hiptislanceolata, Celosia leptoschya has the lowest with the same importance value.

Quadrat Size: $1 \mathrm{~m}$ by $1 \mathrm{~m}$

Table 3. Abundance values obtained from quadrat Samples for plot 3

\begin{tabular}{|l|l|l|l|l|l|}
\hline Species & Density $\left.\mathbf{( M}^{-2}\right)$ & RelativeDensity (\%) & Frequency(\%) & RelativeFrequency (\%) & Importance Value \\
\hline Ageratum conyzoides & 1.8 & 3.92 & 40 & 6.15 & 10.07 \\
\hline Aspiliabussei & 17.7 & 38.56 & 100 & 15.38 & 53.94 \\
\hline Calapagoniummucunoides & 2.5 & 5.45 & 90 & 13.85 & 19.3 \\
\hline Chlorispilosa & 0.7 & 1.53 & 10 & 1.54 & 3.07 \\
\hline Combretumhispidum & 0.2 & 0.44 & 20 & 3.08 & 3.52 \\
\hline Cyperusesculentus & 3.1 & 6.75 & 50 & 7.69 & 14.44 \\
\hline Eleusineindica & 3 & 6.54 & 50 & 7.69 & 14.23 \\
\hline Fimbristylislittoralis & 5.3 & 11.55 & 70 & 10.77 & 22.32 \\
\hline Hiptislanceolata & 0.1 & 0.22 & 10 & 1.54 & 1.76 \\
\hline Ipomoea involucrata & 0.4 & 1.84 & 20 & 3.08 & 4.92 \\
\hline Panicum maximum & 0.7 & 1.53 & 10 & 1.54 & 3.07 \\
\hline Paspalumscrobiculatum & 5.8 & 12.64 & 80 & 12.31 & 24.95 \\
\hline Penniserumpurpureum & 3.9 & 8.5 & 70 & 10.77 & 19.27 \\
\hline Polycarpaeacorymbosa & 0.6 & 1.31 & 20 & 3.08 & 4.39 \\
\hline Sidalinifolia & 0.1 & 0.22 & 10 & 15.38 & 15.6 \\
\hline TOTAL & $\mathbf{4 5 . 9}$ & $\mathbf{6 5 0}$ & & \\
\hline
\end{tabular}


From table 3, results show that Aspiliabussei had the highest density followed by Calapagoniummucunoides, then Paspalumscrubiculatum, while Sidalinifolia, Hiptislanceolata, Panicum maximum and Chlorispilosa had the lowest and same density followed by Combretumhispidum, Ipomoea involucrate and Polycarpaeacorymbosawith the same density. From the table also, results show that Aspiliabussei also had the highest frequency followed by Paspalumscrobiculatum, then Fimbristylislittoralis while Hiptislanceolata had the lowest frequency followed by Panicum maximum and Chlorispilosa with the same frequency. Results also showed that Aspiliabussei had the highest importance value followed by Paspaliumscrobiculatum, then Fimbristylislittoralis while Sidalinifolia and Hiptislanceolata had the lowest and the same importance value followed by Combretumhispidumand Ipomoea involucrata

Table 4. Species diversities for all the plots

\begin{tabular}{|c|c|}
\hline Plots & Species Diversity \\
\hline 1 & 0.79 \\
\hline 2 & 0.78 \\
\hline 3 & 0.75 \\
\hline \multicolumn{2}{|c|}{ Mean $=\frac{0.79+0.78+0.75}{3}=\frac{2.32}{3}=0.77$} \\
\hline
\end{tabular}

From the table it was observed that plot 1 has the highest species diversity followed by plot 2 and plot 3 . In general the mean value of this species diversity is 0.77 which confirms that the area is highly diverse and the species diversity are highly related.The species diversities are not significantly different from one another, showing how homogenous the three plots were.

\section{Conclusions}

From the analysis carried out, results obtained show that the species in the different plots vary a lot in terms of density, frequency, relative frequency, relative density and importance value. Having calculated the species diversity using the Shannon wienner index, results show that plot 1 is the most diverse of the three plots followed by plot 2 and then plot 3. But in all the three plots are highly diverse. The result showed Aspiliabussei had the highest density across the area. It also had the highest importance value because it was present in most quadrat casted in all the plots. The species with the second highest density and importance value across the area is Calapagoniummucunoides. This is followed by Sidaacuta, and Pennissetumpurepureum. This might be due to their adaptive ability to climatic and edaphic conditions. While species like Sidalinifolia, Gompherenacelosoides, Hiptislaceolata, Ipomoea involucrata etc. were low in abundance and are rarely found in the area. This might be due to their inability to adapt to climatic and edaphic conditions. ${ }^{[5]}$ in hisphytosociological study of AbubakarTafawaBelewa University campus, Bauchi observed that Parkiabiglobosa, Sennasiamea were the most abundant species with high importance value index of 52.64 and 19.67 respectively.

\section{REFERENCES}

[1] Ludwig JA and Reynolds JF. Statistical ecology. New York: John Wiley and Sons, Inc. 1988.

[2] McCune B and Grace JB. Analysis of ecological communities. Gleneden Beach, OR: MjM Software Design. 2002.

[3] Tart D, Williams C, DiBendedetto J, Crow E, Girard M, Gordon H, Sleavin K, Manning M, Haglund J, Short B and Wheeler D. Section 2: Existing vegetation classification protocol. In: Brohman, R.; Bryant, L., eds. existingvegetation classification and mapping guide. Gen. Tech. Rep. WO-67. Washington, DC: U.S. Department of Agriculture, Forest Service, Ecosystem Management Coordination Staff; 2-1-2-34, 2005.

[4] Boggs K. Classification of community types, successional sequences, and landscapes of the Copper River Delta, Alaska. Gen. Tech. Rep. PNW-GTR-469. Portland OR: U.S. Department of Agriculture, Forest Service, Pacific Northwest Research Station. 2000.

[5] Usman SS. Nigerian vegetation. Maxson Press. 2004.

[6] Richard PW. The Tropical Rainforest: An Ecological study, Cambridge. Cambridge University press,1996.

[7] Reich PB, Walters MB and Ellsworth DS. Leaf life-span in relation to leaf, plant, and stand characteristics among diverse ecosystems. Ecological Monographs;62: 365-373, 1992.

[8] Richard W. Invasive species specialist groups, global data base. Annals of Botany;21: 287-314, 2005.

[9] Singh L and Singh JS. Importance of short-lived components of a dry tropical forest for biomass production and nutrient cycling. Journal of Vegetation Science;4: 681-686, 1993.

[10] Akobundu IO and Agyakwa CW. A Handbook of West Africa Weeds (2nded.). International Institute of Tropical Agriculture, Ibadan, Nigeria. 1996.

[11] Hutchinson J and Dalziel JM. Flora of West Tropical Africa. 2nd Edition, volume 1, part 2, Crown Agent, Mill Bank, London. 792pp, 1963. 